This is an electronic reprint of the original article. This reprint may differ from the original in pagination and typographic detail.

Author(s): Pöyhönen, Sari; Saarinen, Taina

Title: $\quad$ Constructions of bilingualism in Finnish Government programmes and a newspaper discussion site debate

Year: $\quad 2015$

Version:

Please cite the original version:

Pöyhönen, S., \& Saarinen, T. (2015). Constructions of bilingualism in Finnish

Government programmes and a newspaper discussion site debate. Current Issues in Language Planning, 16(4), 392-408. https://doi.org/10.1080/14664208.2014.979650

All material supplied via JYX is protected by copyright and other intellectual property rights, and duplication or sale of all or part of any of the repository collections is not permitted, except that material may be duplicated by you for your research use or educational purposes in electronic or print form. You must obtain permission for any other use. Electronic or print copies may not be offered, whether for sale or otherwise to anyone who is not an authorised user. 


\section{Constructions of bilingualism in Finnish Government programmes and a newspaper discussion site debate}

Sari Pöyhönen and Taina Saarinen

Centre for Applied Language Studies, University of Jyväskylä, Jyväskylä, Finland

Corresponding author:

Sari Pöyhönen

University of Jyvaskyla *), Centre for Applied Language Studies

P.O. Box 35

FI-40014

University of Jyvaskyla

Finland

*) for technical/conversional reasons letter ä is replaced with letter a

phone: +358.400 .248057$

sari.h.poyhonen@jyu.fi

Taina Saarinen

University of Jyvaskyla*), Centre for Applied Language Studies

P.O. Box 35 
FI-40014

University of Jyvaskyla

Finland

*) for technical/conversional reasons letter ä is replaced with letter a

phone: +358.400 .247970$

email: taina.m.saarinen@jyu.fi

Sari Pöyhönen is professor at the Centre for Applied Language Studies, University of Jyväskylä. Her research focuses on language education policies, minorities and language rights, adult second language education, and notions on language and identity. Her recent publications deal with ethnic and linguistic identities of Ingrian Finnish teachers in Russia; migrants in professional communities; discourses on migration and integration; and policies and practices in adult second language teaching.

Taina Saarinen is Senior Researcher at the Centre for Applied Language Studies, University of Jyväskylä. She is particularly interested in "discursive operationalization" of (language education) policies, and currently works on the theoretical conceptualization of policy as multi-sited and contextualized. Her recent articles deal with the use of textual methodologies in higher education policy studies, conceptualization of policy change, and the invisibility of language in Finnish internationalization policies for higher education. Her research curiosity is mostly sparkled by multidisciplinary research settings, which often make visible new issues and unobserved gaps in the existing research.

Acknowledgements: This work was supported by the Academy of Finland under Grant number 138287.

Word count: 9029 words, including quotations in original language 



\section{Constructions of bilingualism in Finnish Government programmes and a newspaper discussion site debate}

Abstract

The concept of bilingualism in Finnish political discourse is predominantly used in the meaning of official or state bilingualism, focussing on the two constitutionally defined 'national languages'; i.e. Finnish and Swedish. Legally, both Finnish and Swedish speakers have a right for public services, such as schooling or health care, in their first language. On the other hand, several language ideological debates have taken place in recent years, challenging especially the status of Swedish in administration and education. These debates have reshaped the discourses on what counts as bilingualism. This paper analyses on one hand the historical discursive development of the "official will" presented in the Finnish Government programmes on the concept of bilingualism and the current language ideological debates that take place in an Internet discussion site, offered by a Finnish newspaper, on the other. These two discourses seem to operate on separate fields and among different actors. We show that language policy discourses are essentially multi-sited: they confirm, contest and challenge views that are produced by various stakeholders over time.

Keywords: bilingualism, language policy, Finland, language ideological debates, discourse 



\section{Constructions of bilingualism in Finnish Government programmes and a newspaper discussion site debate}

\section{Setting the scene historically and legislatively}

Bilingual Finland has an international reputation as something of a model country with well-functioning bilingual legislation (see for instance a critical analysis by Salo 2012; McRae 2007). It is quite common to start a country report or a scientific article by stating that according to Finnish legislation, Finland is a bilingual country with two national languages, Finnish and Swedish. In principle, this means that both language groups have an equal right for public services, such as schooling or health care, in their first language. The formal policy is, however, only one side of the issue. The position of Swedish in Finland has been topic of more or less heated debates both historically and contemporarily, which implies different, even conflicting interpretations of official policy and its legitimacy. These interpretations of the formal policy, its outcomes and future scenarios have been dealt with in recent policy analyses by researchers (Myntti Kr. 2010; Palviainen 2011; Saukkonen 2013; Ihalainen \& Saarinen in press), former politicians and civil servants (Stenbäck 2003; Geber 2010) and journalists (Myntti Ke. 2010).

The share of Swedish speakers has decreased gradually over a longer period of time. In the mid-19th century, approximately $14 \%$ of the population was Swedish speaking. By the time of the first Republican Constitution of 1919, this share had decreased to approximately $11 \%$. Currently, approximately $5.4 \%$ of the 
population is registered as Swedish speaking. (Finnäs 2004; Statistics Finland 2014.) However, -- and this is indicative of the official policy of state bilingualism and individual monolingualism -- it is only possible to register one mother tongue; thus, bilingualism or multilingualism cannot be reliably compiled in statistics (Latomaa 2012).

During the first decade of the 2000s, social media has brought language ideological debates to the public attention in a new way. Particularly in the field of education, the position of Swedish as a compulsory subject in comprehensive school is under discussion. As we write this paper, the Finnish Parliament is about to start processing a citizen's initiative with over 61000 signatures to change the status of Swedish into voluntary subject in all levels of education. In administration, the rights of the Swedish speaking population to receive official administrative services in Swedish seems to be compromised in some regions and administrative sectors due to the lack of Swedish skills by local authorities. The very recent political debates have focused on the issue of bilingual schools and the status of Swedish in Finnish-medium schools. According to Finnish education legislation, bilingually Finnish-Swedish schools are not allowed. This debate has once again made visible the tensions between official and individual bilingualism in Finland (see Boyd \& Palviainen, in press). It seems, however, that the constitutional status of Finland as a bilingual country as such is currently not under heavy criticism, but the Internet debates and other fora of criticism focus on educational and administrative sectors.

This paper analyses, on one hand, the historical discursive development of the "official language policy will", as constructed in the Finnish Government 
programmes on the concept of bilingualism and, on the other hand, the current language ideological debates that take place in media discussions. We approach our textual data as constructed by various agents, and having intertextual connections with other texts (Fairclough 1992), as well as possessing various degrees of power (Shore \& Wright 1997) over them. Our point of departure is to analyse official bilingualism as presented and constructed in different arenas, and to analyse what kinds of tensions are embedded in the discourses on bilingualism.

Following Johnson's (2009) lines of thinking, we argue that language policy processes are created, interpreted and appropriated (i.e. confirmed and contested) in multiple locations and discourses. Thus, for us, policy processes are not linear (from policy to implementation, from top to down), but dynamic in nature, as various actors are involved, potentially giving input to policy creation, interpretation and appropriation in local practices.

Thus, we will not focus on implementations of legislation, policy outcomes, or how official bilingualism is practiced Finland. Neither do we explore intentions of political parties at a specific time. Instead, we take a policy as discourse orientation (see also Ball 1993). We show that language policy discourses are essentially multi-sited: they confirm, contest and challenge views that are produced by various stakeholders over time. (Halonen \& al., in press.)

\section{Questions and data}

As explained above, we explore both the development of the "official will" of the Finnish government, as presented in legislation and Government programmes, in 
constructing the concept of bilingualism, as well as language ideological debates that have been taken place in media on the status of Swedish. We will focus on the following questions:

- How is bilingualism constructed in the legislation and the Government Programmes?

- How are the official views confirmed, contested and challenged in one discussion site debate?

The first part of our data consists of Government programmes since the independence of 1917 until the latest coalition government 2011. Finnish governments are usually compiled as coalition governments, with a lot of variety right - centre - left in the constellations. The Swedish People's Party (SPP), which is the only party in the current government with an explicit main goal of the nation's bilingualism in its programme, has been a regular government party throughout the Finnish independence. Of the 72 governments, SPP has participated in 49 governments. Of the 23 occasions when SPP has not participated in governments, 20 were either temporary caretaker governments or political minority governments. Thus, most of the time, there has been a party in government with an explicated interest in a bilingual Finland.

Government programmes can be taken as expressions of the government's political will, and - over decades - exceedingly also as operationalizations of that will as development programmes. By the beginning of 2014, there have been altogether 72 programmes, adding up to about 500 pages and ca 87000 words. Until the 1970s, the Governments were relatively short-lived. Also the programmes were short, at first only brief statements of will of one page or even less. Since the 1980 s, and particularly by the 2000 s, these had expanded to 200 - 
page detailed documents (e.g. Katainen's six-party coalition Government 2011), as also the Governments begun to sit the whole four-year election cycle. Descriptive of the increase in text during the 2000 s is that the five programmes of the $2000 \mathrm{~s}$ cover 76 per cent of our whole data.

We analyzed the Government programmes discursively, tracing historical tendencies and changes in the official views 1917-2011 and identifying the discursive spaces that were created in the texts. In our analysis, we focussed particularly on mentions of language (kieli and its derivatives) and bilingualism (kaksikielisyys and its derivatives), and analysed the connotations these terms have over time, producing different discursive spaces (e.g. language and nationbuilding, language and equal rights).

The second part of our data comprises of newspaper discussion forum data from October 8 - 14, 2010, i.e. just prior to the 2011 Parliamentary elections. The data was originally collected for another article (Ihalainen et al. 2011), from the discussion web sites offered by two national Finnish newspapers and one regional newspaper, and it covers the period of intensive web debates sparked by a clash between the then Prime Minister Mari Kiviniemi (Center) and the former Prime Minister Paavo Lipponen (Social Democrats) on the position of Swedish in the context of the regional administration reform. The newspapers in the original data collection (Ihalainen et al. 2011) were Helsingin Sanomat (HS), the biggest Finnish language newspaper; Hufvudstadsbladet (HBL), the biggest Swedish language newspaper; and Vasabladet (VBL), a Swedish language regional newspaper in Ostrobothnia. However, since the net discussions of the Swedish language newspapers, provoked by this particular regional policy news item in October 2010, included altogether only 4 mentions of bilingualism in Finland (three in 
Hufvudstadsbladet and one in Vasabladet), we had to omit that data from further analysis in the article. Thus, the final data from the discussion site offered by Helsingin Sanomat comprises of 265 posts by 172 different pseudonyms.

\section{Official view voiced in the Government programmes}

We identified several periods, where language appeared more prominently in the Government programmes. "Language" is in some context mentioned in 30 Governmental programmes of the total of 72. Particularly the programmes from the years immediately after the Independence (1917), the politically turbulent early 1930s, and the years after the Second World War with the ensuing resettlement of 10 per cent of Finland's then population seemed to call for ensuring national cohesion and internal security. The programmes since 1960s until the 1990s included notable mentions of language, apparently, in turn, for reasons of international co-operation and migration, but also the reorganisation of regional administration since the 1970s. We will analyse the discursive-historical developments more closely in the following.

\section{Languages in nation-building - a balancing act}

Language is an important ingredient in nation-building as many scholars have stated before (e.g. May 2001; Wright 2004; 2012). According to Heller $(1999,7)$ language is central in nation-building in two ways. First, language has a function of constructing a unity: a shared language allows the construction of shared values and practices. The second has a function of legitimizing of a nation: a group 
constitutes a nation, because it shares a language. Thus, the first decade of Finnish independence was devoted to national unity, which can be understood by looking at the historical developments that lead to independence in 1917.

The history of official Finnish - Swedish bilingualism in Finland goes back to the 12th Century and the beginning of the Swedish rule, which also introduced Swedish as the language of the clergy, economics, and policy making. Reformation in the Lutheran church in the beginning of the 16th century gradually introduced Finnish as first the language of the Church, and towards the end of the 18th century, increasingly also as the language of local administration. (Halonen et al., in press.)

With the shift to Russian rule in 1809, the old Swedish legislation was held in force, but the status of Finnish begun to strengthen, as it was seen as an antidote against the influences of Sweden in the newly instated Grand Duchy (Halonen et al., in press). Finnish begun to have a more stable legislative status not only in the Lutheran church, but also in national and local administration. In 1863, Finnish became an official language along with Swedish. The pro-Finnish Fennoman movement (reminiscent of German national romantic movements) and the corresponding Svecomans both strengthened their positions towards the end of the 19th century, leading to a language strife between speakers of Finnish and Swedish. After the Finnish independence in 1917, the new republican Constitution of 1919 and the Language Act in 1922 defined Finland as officially bilingual. (Halonen et al., in press.)

The first years of independence in Finland are characterized by a need to secure national cohesion and internal security. Finland had experienced a devastating civil war which begun only less than two months after the declaration 
of Independence in December, 1917. Around 38500 died or disappeared during the war that lasted from January to May, 1918. The war was not about Finnishspeakers against Swedish-speakers, but a more complex turmoil that concerned political leadership, filling the vacuum that was created after the period of being The Grand Duchy of Finland had ended with the Russian Revolution in 1917. (Karonen \& Holmila 2012).

The historical events and the need to create national unity were clearly present in the first Government programmes. The word 'language' is usually mentioned in conjunction with 'nation', as seen in Ingman's Government programme from 1918:

\footnotetext{
"The duty of the government is to implement the demand of our whole nation, both the Finnish as well as the Swedish language part, that Finland has to be kept intact and untouchable."

"Hallituksen velvollisuus on koettaa saada toteutetuksi koko kansamme, niin hyvin sen suomen- kuin ruotsinkielisenkin aineksen vaatimus, että Suomi on säilytettävä eheänä ja koskemattomana." (GP 3, Ingman, 1918)
}

Unity is constructed in the sixteen Government programmes of the 1920 s by referring to both languages as constituent parts of the nation. The nation needs to stand firmly on its two feet - Finnish and Swedish. Shared values and practices are built on guaranteeing same rights for the two languages, or "both national language groups" (“molemmille kansallisille kieliryhmille”; GP 4 Castrén, 1919), "different language elements of the country" ("maan eri kieliaineisten"; GP 5 Vennola, 1919). 


\section{Majority and minority, and the rest}

Nation-building creates borders not only between states but also ethnic groups. Heller $(1999,7)$ points out that "linguistic minorities are created by nationalisms which exclude them". She continues by arguing that the movements of linguistic minorities reflect, in a smaller scale, the process of nation-building (ibid). In other words, nationalism is necessary in theorizing ethnic minority or minority language.

Swedish, in spite of its official status as a national rather than minority language is infrequently construed as a minority language in Finnish parliamentary debates and other formal discussions (Ihalainen \& Saarinen, in press; Lähteenmäki \& Pöyhönen, in press), thus occupying the discursive space of "minorities". This is also shown in the Government programmes. When talking about majorities and minorities, Swedish speakers are in these instances referred to both as the other part of the nation as well as a minority, whose linguistic rights need to be protected.

The process of keeping balance as a nation between the Finnish majority and the Swedish minority is the leading topic in the Government programmes. The word 'minority' was first mentioned in the late 1920s when the status of Swedish was disputed. Lifting the Finnish national self-esteem was seen as positive effort, but it should not be done at the expense of the Swedish speakers:

\footnotetext{
"Finnish national efforts aimed at, without oppression of the linguistic minority, elevating national self-esteem, will be receiving legitimate attention from the side of the Government." "Suomalais-kansalliset pyrkimykset, joiden tarkoituksena on, kielellistä vähemmistöä sortamatta, kansallisen itsetunnon kohottaminen, tulevat
} 
saamaan hallituksen taholta oikeutettua huomiota osakseen." (GP 15, Sunila, 1927)

In order to create a discursive space for keeping the balance between the two groups, notions on 'nation' or 'people' are used to refer to both groups at the same time. The governments seem to be walking a tightrope in order to please both the majority and the minority. During the first three decades (1920s-1940s) of independence, discourses of unity, co-operation, justice and mutual understanding are the most prominent ones. These discourses can, in turn, be explained by major historical events and the politically unstable times in Finland with, for instance, the nationalistic movements in the 1930s.

Finnish language policy debate is strongly based on constitutionalist arguments, as is evidenced also in the next section on the newspaper discussion site debate. It is indicative of the constitutionally strong position of language policy in Finland that the new Language Act of 2003 was prepared by the Constitutional Law Committee in the Finnish Parliament. (Ihalainen \& Saarinen, in press).

Even though the Constitution could be used as a powerful tool in managing official bilingualism in Finland, it is very rarely used explicitly as an argument in the Government programmes. The Constitution is mentioned for the first time in the late 1930s, as a reaction to the language strife that was visible particularly in the higher education sector and concerning the demands by the Academic Karelia Society to change the University of Helsinki into monolingually Finnish (see Klinge 1990):

"As to the university question, it is the endeavour to reach a solution which satisfies the legitimate demands of the Finnish-speaking majority, while taking 
due account of fulfilling the cultural needs of the Swedish people according to the Constitution."

"Yliopistokysymyksessä on pyrittävä aikaansaamaan ratkaisu, jolla tyydytetään maan suomenkielisen enemmistön oikeutetut vaatimukset, samalla kuitenkin ottaen huomioon ruotsinkielisen kansanosan hallitusmuodossa edellytettyjen sivistyksellisten tarpeiden tyydyttäminen." (GP 22, Cajander 1937)

Another period of need for national unity arose after the Second World War, as Finland fought in the Winter War (1939-40), the Continuation War (1941-1944) and the Lapland War (1944-1945). Over 96000 people were killed or lost, 200000 were disabled, and Finland ended up with the resettlement of over 450 000 Karelians evacuees ( 10 per cent of the population at that time) from the territories lost to the Soviet Union in the Paris Peace Treaty 1947. (Karonen \& Holmila 2012). All these developments put, again, pressure on the national unity. It is thus not a surprise that the other examples of uses of Constitution as an argument in the debate date to the period right after the Second World War in connection to discourses of security and rights. For example, in the Government programme of Paasikivi (GP 30, 1945 ) "all national groups" are called upon to secure the sovereignty of the state ('valtiollisen aseman turvaaminen').

It is interesting that while the War was not about linguistic issues, questions of the security of the Swedish speaking population surfaced in the postWar Government programmes. This was at least partly linked to the Swedish People's Party's opposition of the plans to resettle the Karelian evacuees to Swedish or bilingual municipalities and giving land to them. In the SPPs's parliamentary argumentation, this would have eventually caused "a national Finnishization" ("valtiollisen pakkosuomalaistamisen") of the Swedish regions 
(Karonen 2012). The "sense of security of the country's Swedish-speaking population" (ruotsinkielisen väestön turvallisuuden tunteen) was also later to be promoted (GP 31 Pekkala, 1946), and "the rights of the linguistic minority" (kielellistä vähemmistöä koskevat oikeudet) were to be taken care of "in a constitutional manner" (perustuslakiemme takaamassa järjestyksessä, GP 32 Fagerholm, 1948). Swedish speakers are referred to as "the" linguistic minority throughout the post-War Government programmes.

After the war period, there was almost a decade (1953-1962) when language issues were not mentioned at all, and the discourse of nation filled the space. It was the time of healing war wounds and stressing the unity of the nation, thus closing the period in Finnish history when language and nation occupied a joint discursive link. Since the 1970s, the next peak in mentions of 'language' links it with increasing international co-operation and migration, the increasing European co-operation (culminating in Finland joining the European Union in 1995) and the changes in regional administration policies and the anticipated effects of the regional reform on the services in Swedish.

The word 'bilingual' appears on the scene for the first time in 1970 (GP 53, Karjalainen II, 1970). In the whole Government programme data between 19172011, 'bilingual' or its derivatives is used mostly with reference to municipalities, regions, the country, and other administrative bodies, but only twice with reference to individuals (once to Finnish-Swedish children and once to migrant children). This reinforces Heller's (1999) notion of parallel monolingualisms individuals are construed as monolingual, acting in their own linguistic administrative environments. The languages are self-evidently presented as either Finnish or Swedish, and other languages are rarely explicitly mentioned, or even 
implied. In the Government programmes, bilingualism is thus produced mostly in the context of protecting and maintaining the state bilingualism or upholding services in Finnish and Swedish regionally or locally.

Since the 1980s the form of the Government programmes changes into concrete work plans in order to build a fully functional society. The work plans include discursive operationalizations on how to fulfil the spirit of the Constitution and egalitarian welfare state. Special attention is paid to managing official bilingualism in regions and municipalities, education system, health care, cultural politics and legal services.

\section{Swedish as a compulsory subject in Finnish-medium schools}

The comprehensive school reform in 1968 made language policy issues visible on the everyday policy agenda. The decision to make the national languages mandatory to all pupils was based on cultural policy arguments: the perception of the importance of the Nordic connections (especially during the Cold War) and the desire to cherish and protect the cultural traditions of the country's official bilingualism. Educational equality was also highlighted, and the politicians in favour of the reform wanted to ensure that children living in rural parishes could also have an opportunity to learn the two languages and to have the consequent possibility of educational and social advancement. (Ihalainen et al. 2011.) Until the comprehensive reform, only pupils in the grammar school (oppikoulu, the elite strand of the binary school system) had studied Swedish as a mandatory language. There were, however, also contradictory voices. One of the main arguments against the reform was that studying two languages may be too much for the students (Geber 2010). 
The Government programme of the time was quite laconic, stating that:

The Government will promote cultural policy on a democratic basis. The gradual implementation of the comprehensive school reform will be continued. The question of language teaching in comprehensive school will be readdressed in order to carry out an investigation on the organization of teaching two languages in addition to the mother tongue."

"Hallitus edistää kulttuuripolitiikkaa kansanvaltaiselta pohjalta. Peruskouluuudistuksen asteittaista toteuttamista jatketaan. Kysymys peruskoulun kielenopetuksesta otetaan uudelleen käsiteltäväksi tarkoituksella suorittaa selvitys kahden kielen opetuksen järjestämisestä äidinkielen ohella." (GP 51, Koivisto, 1968).

There has been a fairly broad consensus among Finland's political elite on the mandatory position of Swedish in primary education since the 1960s. The language syllabus (mother tongue + one foreign language + second domestic language) has remained the same since the comprehensive school reform, even though there have been some attempts to change the status quo. (Ihalainen et al. 2011.)

There is a special derogatory word for the mandatory position of Swedish in the Finnish-medium schools, namely "pakkoruotsi" (literally: forced Swedish). The concept deemed to have arisen in 1990, when the Government handed its education and training report to the Parliament. The parliamentary Education Committee made a proposal that Swedish would no longer be mandatory in Finnish-medium schools. The proposal was based, again, on pedagogical arguments, stating that the current language syllabus is too demanding for some of the students. The proposal was rejected in the Parliament after a heated debate. 
The next potential time and place for language debate was offered when the Language Act of 1922 was renewed in the beginning of the 2000s. However, the new Language Act came into force in 2004 without any major public political discussion on the status of national languages in education. (Ihalainen et al. 2011). In the same year, matriculation exams were reformed in the upper secondary schools. Mother tongue was defined as the sole mandatory subject, and thus the second domestic language (Finnish for Swedish-speakers, and Finnish for Swedishspeakers) was moved from mandatory to voluntary. This reform was based on the goal of increasing optionality and students' individual choices. Such a reform was preceded by an eight-year experiment, which the Finnish education political culture can be interpreted as preparation for a permanent arrangement (see Välimaa 1994). Among the Government parties only the Swedish People’s Party opposed the matriculation reform.

\section{Managing bilingualism and multiculturalism}

In the 2000s, the Constitution has become a practical tool for managing (Nikula et al. 2012) official bilingualism. Its spirit, especially its chapter 2 on basic rights and liberties and the section 6 on equality is echoed in discourses of egalitarianism ${ }^{2}$ in the Government programmes: guaranteeing, protecting, maintaining and developing language rights for all citizens, as in the following example:

"Finland belongs to everyone, regardless of place of residence, life situation, mother tongue, or ethnic background. [--] Access to social and health services 
will be guaranteed in Finnish and Swedish and, where possible, they will be provided in Sámi as well."

"Suomi kuuluu jokaiselle asuinpaikasta, elämäntilanteesta, äidinkielestä tai etnisestä taustasta riippumatta. [--] Sosiaali- ja terveyspalveluiden saanti taataan suomen ja ruotsin kielellä sekä pyritään turvaamaan sosiaali- ja terveyspalveluja myös saamenkielisinä." (GP 70, Vanhanen II, 2007)

In the 2000s, bilingualism begins to appear in connection with multiculturalism in the sense that multiculturalism needs to be promoted, but not at the expense of Finnish-Swedish bilingualism. It seems that bilingualism is paralleled with multiculturalism as a form of a reminder discourse of Finnish official bilingualism:

"Multiculturalism and bilingualism will be promoted."

“Monikulttuurisuutta ja kaksikielisyyttä edistetään." (GP 70 Vanhanen II, 2007)

The latest Government programme can also be seen as a Constitutional reaction towards increasing criticism against compulsory Swedish in education and growing inward migration. The populist nationalist party, the Finns Party (previously known as the True Finns) won a landslide victory in the Parliamentary elections of 2011, and was very clear in its programme that Swedish should be a voluntary subject. Also the youth sector of the Coalition Party was in favour of voluntary Swedish, while the Swedish People's Party strongly opposed any changes to the current situation and appealed to Constitutional rights. As a counter measure to the anti-Swedish tendencies, an Action Plan, chaired by former President of the Republic Martti Ahtisaari, was published by the Swedish 
Assembly of Finland (2010) to promote bilingualism in Finland. The programme of Katainen's 2011-2014 six-party coalition (The Finns Party having opted out of the government) explicitly espouses a discourse of pluralism, and offers a counter discourse against critical voices towards official bilingualism:

\begin{abstract}
"Finland's status as a bilingual country is a richness and resource. (--) In Finland, everyone is equal irrespective of gender, age, ethnic origin, language, religion, conviction, opinion, health, disability, sexual orientation, or any other individual factor."

"Suomen kaksikielisyys on rikkaus ja voimavara. (--) Suomessa kaikki ovat samanarvoisia sukupuolesta, iästä, alkuperästä, kielestä, uskonnosta, vakaumuksesta, mielipiteistä, terveydestä, vammaisuudesta, seksuaalisesta suuntautumisesta tai muusta henkilöön liittyvästä syystä riippumatta. " (GP
\end{abstract} 72, Katainen II, 2011)

In sum, the Government programmes have throughout Finnish history aimed at reconciling the needs of the Finnish-speaking majority and Swedishspeaking minority and produced a discursive space, in which both languages are independent and equal. This discourse produces a monolingual norm of the speakers of the languages - official bilingualism is de facto societal bilingualism, not individual bilingualism. The situation is currently tested particularly in the field of education, as the citizen's initiative mentioned in our introduction indicates.

The official discourses in the Government programmes have shifted from unity of the bilingual nation to securing and protecting minority rights, and finally, managing bilingualism through administrational tools. Next, we continue the analysis by focusing on how state bilingualism is confirmed, contested and 
challenged in the newspaper net forum discussions on the mandatory position of Swedish in Finnish-medium schools.

\section{Discussion site debates on the position of mandatory Swedish}

Next, we move on to the analysis of a recent example of a newspaper discussion site debate concerning some aspects of bilingualism in Finland. The criticism towards official language policies is nowadays channelled easily via Internet fora, where various pressures concerning Finnish language policies are relieved. On the other hand, it seems that Internet debates are fairly concentrated: like-minded writers operate on their own fora, and active writers produce most of the texts (Saukkonen 2011). In our case, the discussion in the forum could be conducted by using pseudonyms, but Helsingin Sanomat had introduced a compulsory registration for anyone wishing to post to the site immediately before the debate took place.

What makes the discussion sites interesting in comparison with the Government programmes is their potential for criticism of the political mainstream. For obvious reasons, Government programmes are not the genre where official government policies are criticised; their format is that of promoting and concretizing the formal policy goals of the current government. As Finnish governments have in recent decades been majority governments (the last minority government being that of Martti Miettunen's Centre minority government in 197677), the Government programmes reflect the views of the ruling political elite rather than criticize it. 
The discussion site debates, in turn, reflect a lot of criticism of the ruling elites also in language questions. It is also typical of Finnish Internet discussions that while the debate that we have as our data started with a regional policy angle of whether residents of a particular Ostrobothnian area would be receiving services in their mother tongue, the discussion very quickly turned towards the position of Swedish as a mandatory language in education.

\section{Reaction to tradition of constitutional bilingualism}

The newspaper discussion forum debaters easily seem to draw on the Constitution for arguments in the language debate. The Finnish language debate in Helsingin Sanomat included several references to the Constitution both as static and as changeable, depending on the discussants motivations and line of argumentation.

The following examples construe the Finnish Constitutional bilingualism as fundamentally static:

According to the Constitution Finland is a bilingual country. I don't understand this fuss.

Suomi on perustuslain mukaan kaksikielinen maa. En ymmärrä tätä kohua. ("Mielipide", October 8, 2010, Helsingin Sanomat) ${ }^{3}$

Do you understand how small this country of ours is, and how important it is to treat all our citizens equally, regardless of colour, language, religion and residence, as stipulated by our Constitution. 
Tajuatko, miten pieni tämä maamme on, ja miten tärkeää on se, että kaikkia kansalaisiamme väristä, kielestä, uskonnosta ja kotipaikasta riippumatta kohdellaan tasapuolisesti, kuten perustuslakimme määrää. ("Maalaismummo" 08.10.2010, Helsingin Sanomat)

The writer of the latter excerpt quotes explicitly 'colour, language, religion and residence' as being named in the Constitution, whereas the Constitution of 1999 refers to 'gender, ager, ethnic origin, language, religion, conviction, opinion, state of health, disability or other individual reason'. Both the above arguments assume that the constitutional bilingualism of Finland implies compulsory Swedish in education. Further, the second example above construes Constitutional bilingualism strongly in first person plural as ours. This strategy is reminiscent of the parliamentary debates where particularly the representatives of the Swedish People's Party construed a strong political consensus on the Finnish speaking majority's support for bilingualism (Ihalainen \& Saarinen forthcoming).

While the previous extract used the concept of equality to defend compulsory Swedish, the Constitution was also criticized for promoting inequality and "minority dictatorship", simultaneously construing Finnish speakers discursively as the "victims" of this policy:

Of course the issue has been settled in the Constitution, but if we dared to observe this objectively, we would see serious discrimination of the majority or minority dictatorship. Hardly in any country has this small a minority gotten such huge privileges. That the majority is forced to learn the language of a small (albeit important) minority is definitely not following principles of human rights, nor equality and equal rights.

Asia on toki päätetty perustuslaissa, mutta jos asiaa uskallettaisiin tarkastella objektiivisesti, tässä nähtäisiin vakavaa enemmistön syrjintää tai vähemmistödiktatuuria. Tuskin missään maassa koskaan näin pieni 
vähemmistö on saanut näin valtaisat etuoikeudet. Se että enemmistö joutuu pakosta opettelemaan pienen (vaikkakin historiallisesti tärkeän) vähemmistön kielen, ei taatusti ole ihmisoikeusperiaatteiden eikä tasa-arvon tai yhdenvertaisuuden mukaista. ("Väkilukufaktat" 08.10.2010, Helsingin Sanomat")

Not all arguments saw the Constitution as static and unchangeable. There were also examples in which the Constitution was construed as something that is made by humans and can also be changed by them:

The Constitution (not to mention the Language Act or Basic Education Act) has not been given to us from the above but has been written by men."

Perustuslaki (kielilaista tai perusopetuslaista puhumattakaan) ei ole meille ylhäältä annettua, vaan se on ihmisten säätämä. ("Väkilukufaktat” 08.10.2010, Helsingin Sanomat)

The religious metaphor of the Constitution not being "given from the above" implies that the opposing party presented the Constitution as divine and thus unchangeable.

A further twist in the constitutional arguments was brought by a stand taken by the then chair of the Constitutional Law Committee, Kimmo Sasi (Coalition) in June 2010; i.e. less than four months before our data was collected. In a letter to the editor, Sasi defended mandatory Swedish and Finnish at comprehensive school (Sasi 2010) by interpreting the constitutional position of Finnish and Swedish from the point of view of individual's rights: since the Constitution guarantees each individual the right to receive services in his/her mother tongue (i.e. Finnish or Swedish), it is necessary that both national 
languages are taught at school. This, and probably also Sasi's active position in several Finland Swedish organisations, sparked a brief exchange also in our data on the status of the Constitution in mandatory language teaching:

Kimmo Sasi wrote (AL 17.6. 2010) that the constitution stipulates that every Finnish language pupil has to learn Swedish. Since the writing is published in the name of the Constitutional Law Committee, it can be interpreted so that this is the official state stand on the issue. My own "educational career" consist of primary school, vocational school and technical school which I graduated from in 1970. At no stage was I required to study Swedish. In other words, I am a person who should not, according to the Constitution, exist. Kimmo Sasi kirjoitti (AL 17.6.2010 ) että perustuslaki määrää jokaisen suomenkielisen koululaisen opiskelemaan Ruotsin kieltä. Kun kirjoitus julkaistaan perustuslakivaliokunnan nimissä, lienee tulkittavissa että tämä on valtiovallan virallinen kannanotto. Oma " koulutusurani" on kansakoulu, ammattikoulu ja teknillinenkoulu, josta pääsin v-70. Missään vaiheessa minun ei tarvinnut opiskella Ruotsin kieltä. Olen siis ihminen jota perustuslain mukaan ei saa olla olemassa. ("Ilmari” 09.10.2010, Helsingin Sanomat)

The above writer's ironic reference to the impossibility of his/her existence also suggests a view that politicians have become remote from "real life" in stressing the Constitution over people's lived experiences.

A counter-reaction to this was presented by another writer who defends the Constitutional interpretation, and how it should be appropriated, presented by Sasi. The writer also refers to mandatory Swedish as a question of educational equality:

Ordinary laws cannot contradict the Constitution. Even if some issue is not explained in one-syllable words in an ordinary law, the constitutionalism of the individual laws is interpreted by the Constitutional Law Committee, chaired by Sasi. It also takes into consideration the background work for each 
law. Swedish language services need to be secured somehow. It can also be done the way it was done in earlier years. Swedish was compulsory only in grammar school, and the unwilling and unable were taught only mother tongue. We can easily go back into that. It may even make sense, since not everyone will learn languages, no matter what.

Tavalliset lait eivät voi olla ristiriidassa perustuslain kanssa. Vaikka tavallisessa laissa ei nyt joka asiaa väännetäkkään rautalangasta niin lakien perustuslakienmukaisuutta tulkitsee juuri Sasin johtama perustuslakivaliokunta. Se ottaa huomioon myös lain perustelut eli esityöt. Jotenkin ruotsinkieliset palvelut on turvattava. Se voidaan myös tehdä kuten tehtiin ennen. Ruotsi oli pakollista vain ns.oppikoulussa. Tällöin haluttomille ja kyvyttömille kansakoulussa ei opetettu kuin äidinkieltä. Kyllä siihen voidaan hyvin mennä. Kuulostaa jopa järkevältä sillä kaikki eivät opi kieliä vaikka kuinka päähän takoisi. ("Vesa Kaitera” 11.10.2010, Helsingin Sanomat)

While the teaching of Swedish either as mandatory or voluntary was argued with constitutional arguments, the constitutional position of Swedish as the second national language was rarely challenged; most discussions focussed on education. In one rare occasion, also the constitutional position of Swedish is seen as historically obsolete:

Why fight the inevitable. Time is simply passing by the constitutional privilege of the Swedish language.

Miksi taistella tutkainta vastaan. Aika on yksinkertaisesti ajamassa ruotsin kielen perustuslaillisen etuaseman yli. ("sdp" 08.10.2010, Helsingin Sanomat)

It thus seems that the Constitution can in the debate provided by the Helsingin Sanomat discussion site be referred to both defend the position of mandatory Swedish (by presenting Swedish skills as necessary for upholding citizens' equal rights for services) and to argue for voluntary Swedish (as presenting the Constitution as a law like others). In our Swedish language debate data, on the other hand, the Constitution seems to be a non-issue, as it is mentioned extremely 
rarely, and then mainly neutrally. In conclusion, the implied constitutional arguments in the Government programmes are explicitly either supported or opposed in the Finnish language media debates.

\section{Newspaper net forum discussions as criticism of political elite}

In our data that focussed on a regional policy aspect of the realization of linguistic rights of the Swedish speakers, criticism of mandatory Swedish inevitably also appears as a question reflecting differences between the political elite and the popular opinion.

In the following example, the writer cites recent surveys which indicate that about 60-65 per cent of the population are opposed to the mandatory teaching of Swedish 4 . The writer then goes on to refer to the arguments of "experts" (which are not named) and the biggest Finnish employer organisation, and concludes that since both the majority of the people and the cited experts are against mandatory Swedish, its survival can only be due to the 'lackeys' of the Swedish People's Party in Finnish speaking political parties.

The matter of forced Swedish is more profound in the sense that it tells a grim tale of how politicians act. Forced Swedish is opposed by approximately $2 / 3$ of the population, and also by many experts and the Confederation of Finnish Industries. Forced Swedish is mainly advocated by the SPP and its lackeys in other political parties.

Pakkoruotsiasia on siinä mielessä syvällisempi juttu, että se kertoo karua kieltään poliitikkojen toimintatavoista. Pakkoruotsia vastustaa noin $2 / 3$ kansalaisista, lukuisat asiantuntijat ja mm. Elinkeinoelämän keskusliitto. 
Pakkoruotsia kannattaa lähinnä RKP sekä RKP:tä hännystelevät muiden puolueiden poliitikot. ("Lipposen 08.10.2010, Helsingin Sanomat)

Internet debates tend to turn rather heated on occasions in comparison to face-toface dialogue (Saukkonen, 2011). Helsingin Sanomat had in October 2010 (i.e. just before our data was collected) made a decision of requiring all discussion forum writers to register with an alias. The purpose of this was to encourage moderate and well argued discussion in the newspaper's discussion forum. This may have had an influence on the Helsingin Sanomat debate. However, when the writers turned their criticism towards the political elite or individual politicians, the tone turned harsh:

\footnotetext{
"This is a question of democracy, and if people's will is not realized through democracy and the feeling of injustice prevails, we have chosen a dangerous path."

Kysehän on demokratiasta, jos demokratian keinoin ei kansan tahto toteudu ja syntyy yhä suurempi tunne epäoikeudenmukaisuudesta, niin ollaan vaarallisilla teillä. ("nimimerkki” 08.10.2010, Helsingin Sanomat)
}

The above example juxtaposes the feelings of injustice strongly with the perceived lack of democratic processes, and concludes with something that can either be interpreted as a prediction of the future (i.e. something dangerous may happen) or as a thinly veiled threat (something dangerous will happen).

The next writer analyses mandatory Swedish as an example of the distorted interpretation of customary law by the political elite. The author explicitly suggests that it has become customary for politicians to ignore the popular opinion and "obey" the interests of the Swedish People's Party. The writer concludes by suggesting that it would be time to finish with this interpretation of the custom, implying that this would lead democracy: 
If, then, a politician does not listen to the majority of the people and think of the good of the country, but rather obeys a small interest group (the Swedish People's Party), then s/he is likely to conduct other business in the same manner. This kind of action, which degrades democracy, is probably known as 'customary law'. But is it time to give up this custom? Jos siis poliitikko ei tässä asiassa kuuntele kansan enemmistöä eikä ajattele koko maan etua, vaan tottelee mieluummin pientä etujärjestöä (RKP), niin todennäköisesti hän hoitaa samalla periaatteella montaa muutakin asiaa. Tällainen demokratiaa halventava toiminta taidetaan tuntea myös termillä 'maan tapa'5. Mutta olisiko jo aika luopua tästä maan tavasta? ("Lipposen” 08.10.2010, Helsingin Sanomat)

The presentation of the political elite as biased against "Finns" and "Finnish" is culminated in the following example, where Paavo Lipponen and the Social Democratic Party are presented as the ultimate racists in the Finnish political system. The criticism is directed at the party and its former chairman, implying that the Social Democrats represent the ruling elites:

The next elections will make sure that the 'Berlin Wall' of language policy, built by the elite, will break and the racist discrimination against the Finns will come to an end. In his public disclosure Lipponen will only make sure the tarnishing of his own image and the final defeat of the Social Democrats. Seuraavat vaalit varmistaa, että eliitin rakentama kielipolitiikan 'Berliinin muuri' murtuu ja suomalaisten rasistinen syrjintä loppuu. Julkitulollaan Lipponen vain varmistaa oman imagonsa likaantumisen ja SDP:n lopullisen häviön. ("karrister" 08.10.2010, Helsingin Sanomat)

Incidentally, the 'next elections' (i.e. parliamentary elections in April 2011) saw the landslide victory of the populist Finns party (with a 34 seat increase in seats and a 15 percentage point increase in votes), whereas the biggest election loser was the 
Centre (with a loss of 16 seats and 7.4 percentage points) rather than the Social Democrats. The critique against the ruling political elite proved to be more widespread than maybe anticipated by the major parties before the parliamentary elections. The pro-Swedish stand of the major political parties is probably just one, albeit visible, reason for this.

It appears that political elites (both as individuals and as parties) are accused of being either corrupt or ignorant in their defence of mandatory Swedish in the Helsingin Sanomat discussion site debates. This critique of the political elites is apparent not only in language policy, but other policy sectors as well (Ihalainen et al. 2011).Historically, this critique is interesting since in the $19^{\text {th }}$ century it was the Swedish speaking political elite that begun to promote the use of Finnish in official domains (Coleman 2010).

\section{Discussion}

The official views on Finnish bilingualism have not changed considerably during the Finnish independence, and the discourses tend to be quite hygienic, whereas public debates have surfaced only occasionally, for example during the politically tumultuous 1930s or the comprehensive school reform of the 1960s. Official bilingualism, as featured in the Government programmes, is defined as societal bilingualism rather than individual bilingualism. The state, the nation, and the bilingual municipalities consist of two groups of speakers of Finnish and Swedish, which are inherently monolingual.

Nevertheless, there have been several debates on the position of Swedish in Finland during the past 90 years. These debates have illuminated the discourses 
and counter-discourses on what counts as bilingualism, and how the experiences of the 'victims of the bilingualism policy and practice', as presented earlier in our analysis, are overlooked in the national policy-making. The debates - as it is quite often the case - tend to be polarized, thus making visible the multiple policy arenas.

All in all, societal bilingualism in Finland presents an example of what Heller (1999; 2007) has termed "parallel monolingualism", where languages are used in their own spheres (see also Nikula et al. 2012; Boyd \& Palviainen, in press). The smallest societal unit is a bilingual family, in which one parent is a monolingual Finnish-speaker, and other parent monolingual Swedish-speaker, and their children bilingual speakers, maybe registered as Finnish speakers but nonetheless going to a Swedish-medium school. Thus, Finnish Government programmes reflect an understanding of state bilingualism as a solid reality, based on an understanding of the Constitution as something permanent and untouchable (Ihalainen \& Saarinen, in press). While the state is societally bilingual, it seems that construction of individual Finnish-Swedish bilingualism is not ideologically possible in the formal policy of legislation and Government programmes. The strong political position of the Constitution appears to lock the debate in this respect.

In the Helsingin Sanomat web discussions, individual bilingualism is virtually absent as well, but contrary to the official discourses, the tendency is to build a picture of one nation and one language, as opposed to the constitutional one nation and two languages construction. It seems to be very difficult for a bilingual Finnish-Swedish speaker to draw on bilingual language rights, because bilingualism is constructed through de facto monolingualism. Societal bilingualism 
is seen as the norm and individual bilingualism as somewhat invisible or nonexistent. This reflects the "Taxell paradox", credited to a former chairman of the SPP and a Government minister, Christoffer Taxell: monolingual institutional solutions lead to a maintenance of societal bilingualism, whereas bilingual institutional solutions tend towards a monolingual society (Boyd \& Palviainen, in press).

The analysis of the Government programmes also shows that when bilingualism is mentioned, it is actually solely about Swedish. There is very little space for other kind of bilingualism (either societal or even to a lesser degree individual) - or Finnish for that matter. In the official views and especially in the Internet debates, Swedish is the elephant in the room (cf. Wright 2009). The official views create a discourse of tiptoeing, where issues of individual bilingualism and multilingualism are hushed under a surface of societal bilingualism, and creating a set of mental notes focussing on the rights of the Swedish-speaking minority in managing societal bilingualism. Thus, the official discursive space is filled with a complex mixture of constructing Swedish both as a national language and a minority language. The notions of societal bilingualism can also be seen as a means to govern (Rose 1999) the "messy realities" and conflicting discourses of multilingualism, a tool in order to preserve the high modern status quo of national language ideologies (Nikula et al. 2012). This 'official will' is made visible by the discourses of management, securing and protection (see also Boyd \& Palviainen, in press, for discussion of rights/resource/problem).

The newspaper discussion site debate in our sample is energized by the explicit critique of official bilingualism that is devoted to Swedish only and ignoring the "people's will". The critique is mainly targeted against the political 
elite and the state of democracy, and making visible the tensions behind the constitutional wall. In 2014, for the first time in Finnish history, the number of speakers of other languages than Finnish, Swedish and Sami, exceeded the number of Swedish speakers. This will most certainly give more fuel for language debates on the position of Swedish as a national language.

As we have shown in our article, language policy discourses are essentially multi-sited, conflicting and complex. The official, institutional language policy on bilingual Finland, reproduced and reinforced in public statements by Government party chairmen and other top politicians, is increasingly challenged by developments in other policy sectors such as education and regional administration. These cracks in the official policy are eagerly broadened by actors in Internet debates or used as arguments in citizen's initiatives. The static official view of individual monolingualism and institutional bilingualism is under pressure from various sides in this multi-sited debate.

\section{References}

Ball, S. (1993). What is policy? Texts, trajectories and toolboxes. Discourse, 13(2), 10-17.

Blommaert, J. (1999). The debate is open. In Blommaert, J. (ed.) Language ideological debates. Berlin: Mouton de Gruyter, 2-38.

Boyd, S. \& Palviainen, Å. (2015). Building walls or bridges? A language ideological debate about bilingual schools in Finland. In M. Halonen, P. Ihalainen \& T. Saarinen (eds.) Language Policies in Finland and Sweden: Interdisciplinary and multi-sited comparisons (pp. 57-89). Bristol: Multilingual Matters. 
Canagarajah, S. (2006). Ethnographic Methods Language Policy. In T. Ricento (ed.) Language Policy. Theory and Method, 153-169. Malden, MA: Blackwell.

Coleman, M. (2010) 'You might all be speaking Swedish today': Language change in $19^{\text {th }}$-century Finland and Ireland. Scandinavian Journal of History 35 (1), 44-64.

Geber, E. (2010). Den obligatoriska svenskan i Finland. En historisk analys. [Compulsory Swedish in Finland. A historical analysis.] Helsinki: Magma. Retrieved http://www.magma.fi/images/stories/reports/mpm1_obligatoriskasvensk an.pdf

Fairclough, N. 1992. Discourse and social change. Cambridge: Polity Press. Finnish Constitution (1999). Suomen perustuslaki. 731/1999. Finlex.

Finnäs, F. 2004. Finlandsvenskarna 2002. En statistisk rapport. Helsingfors: Folktinget.

Halonen, M., Ihalainen, P. \& Saarinen, T. (2015). Diverse discourses in time and space. Historical, discourse analytical and ethnographic approaches to multi-sited language policy discourse. In M. Halonen, P. Ihalainen \& T. Saarinen (eds.) Language Policies in Finland and Sweden: Interdisciplinary and multi-sited comparisons (pp. 3-26). Bristol: Multilingual Matters.

Heller, M. (1999). Linguistic Minorities and Modernity: A Sociolinguistic Ethnography. London: Longman.

Heller, M. (2007). Bilingualism: as ideology and practice. In M. Heller \& M. MartinJones (eds.) Bilingualism: a Social Approach. Basingstoke: Palgrave Macmillan, pp. 1-22.

Ihalainen, P. \& Saarinen, T. (2015). Constructing 'language' in language policy discourse: Finnish and Swedish legislative processes in the 2000s. In M. Halonen, P. Ihalainen \& T. Saarinen (eds.) Language Policies in Finland and Sweden: Interdisciplinary and multi-sited comparisons (pp. 29-56). Bristol: Multilingual Matters.

Ihalainen, P., Saarinen, T., Nikula, T., Pöyhönen, S. (2011). Aika kielipolitiikassa. Päivälehtien nettikeskustelujen historiakäsitysten analyysi. [Time in the politics of language. An analysis of the conceptions of history in the Internet discussion fora in Finnish newspapers.] Kasvatus \& Aika 3, 1797-2299. 
Johnson, D. C. (2009). Ethnography of language policy. Language Policy 8: 139159.

Karonen, P. (2012). Pitkä parlamentti ja rauhaan palaaminen toisen maailmansodan jälkeen. [The "Long Parliament" and the return to peace after the Second World War.] In M. Enbuske, M. Mäntylä, M. Salo \& R. Satokangas (eds.) Historian selkosilla Jouko Vahtolan juhlakirja. Studia Historica Septentrionalia 65 (pp. 163-172). Vaasa: Pohjois-Suomen historiallinen yhdistys.

Karonen, P. \& Holmila, A. (2012). La guerra y la paz en la historia de Finlandia: 15901950. [War and Peace in the History of Finland: Social and Political Impacts in Longue Durée, 1590-1956.] Istor 48 (2012), 68-94.

Klinge, M. (1990). Vallankumouksesta talvisotaan. [From the Revolution to the Winter War] In M. Klinge (Ed.), Helsingin yliopisto 1640-1990, osa III: Helsingin yliopisto 1917-1990. [University of Helsinki 1640-1990, part III: University of Helsinki 1917-1990] Helsinki: Otava, 9 - 120.

Latomaa, S. (2012). Kielitilasto maahanmuuttajien väestönosuuden mittarina. [Language statistics as indicators of share of migrant population.] Yhteiskuntapolitiikka 77 (2012): 5, 525-534.

Lähteenmäki, M. \& Pöyhönen, S. (2015). Language rights of the Russian-speaking minority in Finland: Multi-sited historical arguments and language ideologies. In M. Halonen, P. Ihalainen \& T. Saarinen (eds.) Language Policies in Finland and Sweden: Interdisciplinary and multi-sited comparisons (pp. 90-115). Bristol: Multilingual Matters.

May, S. (2001). Language and minority rights: Ethnicity, nationalism, and the politics of language. London: Longman.

McRae, K. D. (2007). Toward language equality: Four democracies compared. International Journal of the Sociology of Language 187/188, 13-34.

Myntti, Ke.(nneth) (2010). Svenskan på offensiven eller på intensiven. [Swedish on the offensive or intensive care.] Helsinki: Söderströms. 
Myntti, Kr.(istian) (2010). Nationalspråk och minoritetsspråk i ljuset av finländsk lagstiftning och internationella konventioner. Retrieved http://www.kulturfonden.fi/Site/Data/686/Files/Publikationer/Nationals prak\%20och\%20minoritetssprak2010.pdf

Nikula, T., Saarinen, T., Pöyhönen, S. \& Kyllönen, T. (2012). Linguistic diversity as problem and resource: Multilingualism in European and Finnish policy documents. In J. Blommaert, S. Leppänen, P. Pahta \& T. Virkkula (eds.) Dangerous Multilingualism - Northern Perspectives to Order, Purity and Normality. Basingstoke: Palgrave, pp. 41-66.

Palviainen, Å. (2011). Frivillig svenska? Utbildningsrelaterade konsekvenser. [Optional Swedish? Education related consequences.] Helsinki: Magma. Retrieved at http://www.magma.fi/images/stories/reports/ms1103_frisv.pdf

Rose, N. (1999). Powers of Freedom: Reframing Political Thought. Cambridge: Cambridge University Press.

Salo, O.-P. (2012). Finland's Official Bilingualism - a Bed of Roses or of Procrustes? In J. Blommaert, S. Leppänen, P. Pahta \& T. Räisänen (eds.) Dangerous Multilingualism. Northern Perspectives on Order, Purity and Normality. London: Palgrave Macmillan, pp. 25-40.

Sasi, K. (2010). Katainen noudattaa puoluekokouksen tahtoa ja perustuslakia. [Katainen follows the will of the party convention and the Constitution]. Letter to the Editor. Aamulehti, 17 June, 2010. Retrieved http://www.kimmosasi.net/mielipidekirjoitus-ruotsin-kiele/

Saukkonen, P. (2011). Mikä suomenruotsalaisissa ärsyttää? Selvitys mediakeskustelusta Suomessa. [What's irritating about Finland Swedes? Report on media debates in Finland]. Magma-Studie 1-2011. Helsinki: Magma. Retrieved http://www.magma.fi/images/stories/reports/ms1101_mikasu_s.pdf Saukkonen, P. (2013). Erilaisuuksien Suomi. Vähemmistö- ja kotouttamispolitiikan vaihtoehdot. [Finland as country of differences. Alternatives for minority and integration policies.] Helsinki: Gaudeamus. 
Shore, C. \& Wright, S. (1997). Policy: A new field of anthropology. In C. Shore \& S. Wright (eds.) Anthropology of policy. Critical perspectives on governance and power. Milton Park: Routledge, pp. 3-39.

Statistics Finland 2014. Retrieved http://www.stat.fi/

Stenbäck, P. (2003). Vision och verklighet. Handbok i överlevnad för Svenskfinland.

[Vision and reality. Handbook on the survival of Swedish Finland.] Helsinki: Söderströms.

Välimaa, J. (1994). A Trying Game: Experiments and Reforms in Finnish Higher Education. European Journal of Education 29 (2), 149-163.

Wright, S. (2004). Language Policy and Language Planning. From Nationalism to Globalisation. London: Palgrave Macmillan.

Wright, S. (2009). The elephant in the room: language issues in the European Union. European Journal of Language Policy, 1 (2), pp. 93-119.

Wright, S. (2012). Language policy, the nation and nationalism. In B. Spolsky (ed.) The Cambridge Handbook of Language Policy. Cambridge: Cambridge University Press, pp. 59-78. 


\section{ENDNOTES}

${ }^{1}$ References to Government programmes are made by their progressive number, the last name of the Prime minister, and the year the programme was published. All translations are the authors'.

2 'No one shall, without an acceptable reason, be treated differently from other persons on the ground of sex, age, origin, language, religion, conviction, opinion, health, disability or other reason that concerns his or her person’ (Finnish Constitution 1999).

${ }^{3}$ Discussion site posts are referred to by the alias, date, and name of the newspaper.

${ }^{4}$ Several recent opinion polls have indicated that approximately 50-63 percent of the population are in favour of voluntary Swedish in education. These polls have been commissioned by actors which may have a political interest in the field (such as the pro-Finnish Suomalaisuuden Liitto(Association of Finnish Culture and Identity) or Ajatushautomo Magma (Think tank Magma) which promotes a bilingual Finland. Both organizations have, however, commissioned their polls by the same research institution Taloustutkimus, but with differing questions; Suomalaisuuden Liitto asking, whether Swedish should be voluntary (63 percent of the respondents favouring this) and Magma, in turn, whether it should be compulsory (50 per cent of respondents in favour of this).

5 The Finnish maan tapa (literally “way of the country”), originally meaning customary law or undisputed legal practices, has increasingly gotten the connotation of distorted or corrupted practice of politicians, usually in order to gain personal benefits. 